\title{
EPSL
}

ELSEVIER

Earth and Planetary Science Letters 173 (1999) 315-331

www.elsevier.com/locate/epsl

\section{A Late Pleistocene clockwise rotation phase of Zakynthos (Greece) and implications for the evolution of the western Aegean arc}

\author{
C.E. Duermeijer ${ }^{\text {a, } *}$, W. Krijgsman ${ }^{\text {a }}$, C.G. Langereis ${ }^{\text {a }}$, J.E. Meulenkamp ${ }^{\text {b }}$, \\ M.V. Triantaphyllou ${ }^{\mathrm{c}}$, W.J. Zachariasse ${ }^{\mathrm{b}}$ \\ a Paleomagnetic Laboratory 'Fort Hoofddijk', Faculty of Earth Sciences, Utrecht University, Budapestlaan 17, \\ 3584 CD Utrecht, Netherlands \\ ${ }^{b}$ Department of Geology, Faculty of Earth Sciences, Utrecht University, Budapestlaan 4, 3584 CD Utrecht, Netherlands \\ ${ }^{c}$ Department of Geology and Paleontology, Panepistimiopolis 15784, Athens University, Athens, Greece
}

Received 19 April 1999; accepted 9 September 1999

\begin{abstract}
Palaeomagnetic measurements have been carried out on Eocene to Pleistocene sediments on the Ionian island of Zakynthos, NW Greece. Magnetostratigraphic constraints, biostratigraphic analyses of planktonic foraminifera and calcareous nannofossils provide a reliable time frame for these deposits. The results show that no significant rotation occurred between 8.11 and $0.77 \mathrm{Ma}$, but that Zakynthos underwent a $21.6^{\circ} \pm 7.4^{\circ}$ clockwise rotation between $0.77 \mathrm{Ma}$ and Recent. Thus, our data indicate a rapid rotational event, in contrast to continuous rotation since $5 \mathrm{Ma}$ as previously postulated [Laj et al., Tectonophysics 86 (1982) 45-67]. We speculate this late Pleistocene tectonic rotation phase to be linked to rapid uplift in the Greek region which results from rebound processes caused by (African) slab detachment underneath the Ionian islands. () 1999 Elsevier Science B.V. All rights reserved.
\end{abstract}

Keywords: palaeomagnetism; tectonics; rotation; Mediterranean region; Aegean Islands; Neogene

\section{Introduction}

The main part of Greece belongs to the Hellenides, an approximately NW-SE-running orogenic belt which forms the connection between the mountain chains of the Dinarides (northern Albania and former Yugoslavia) in the west and the Taurides (Turkey) in the east. The Hellenides are divided into a number of sedimentary facies belts or isopic zones [1] from internal (east) to external (west): Vardar,

\footnotetext{
* Corresponding author. Tel.: +31 30253 5418; Fax: +31 30
} 253 5030; E-mail: duermeij@geo.uu.nl
Pelagonian, Pindos, Gavrovo-Tripolitsa, Ionian and Pre-Apulian zone. These zones are separated by major NW-SE-striking thrusts on the Greek mainland and on the Ionian Islands. The geological evolution of the Hellenides is dominated by divergence and convergence of the African and Eurasian plates [1] and related processes like subduction, roll back followed by extension in the Aegean back-arc, and possibly an additional westward Anatolian push. During Mesozoic times, troughs and platforms developed between the foreland, Adria (the African promontory), and the internal oceanic part of the Neotethys. Subsequently, the oceanic part closed and the dif- 
ferent isopic zones were emplaced as well-defined thrust sheets. The timing and locus of emplacement migrated progressively towards the foreland [2]. The (outer) westernmost thrust zone, the Ionian thrust, was probably active during the Early Pliocene [3].

The current southern and western boundaries of the deforming Aegean region are formed by the subduction (Hellenic trench system) of the African slab underneath Eurasia, with Adria separating Greece from Italy. Tomography has shown that subduction occurred at both sides of Adria [4]. The seismic velocity structure reveals detachment of the (African) slab from the surface in northern Greece [4] and beneath the Calabrian arc in southern Italy [5]. According to Wortel and Spakman [6] the detachment of the slab started in the north and migrated southwards in time, causing temporal and spatial variations in the slab pull. Where the slab is just detached, a basin (deflection downward) can develop, succeeded by a period of rebound processes in which the area will be uplifted. Although other authors have used tomography data to propose a continuous slab in southern Italy and Greece $[7,8]$ there is a growing number of studies, e.g. on migration of depocentres along the Apennines [9], that are consistent with the process of migration of slab detachment.

Over the last decades, palaeomagnetic studies have aided in the understanding of the Neogene geodynamic evolution of the Aegean arc (Fig. 1). Kissel and Laj [12] concluded that the curvature of the Aegean arc has been acquired by deformation during two major tectonic phases, an older one during the Middle Miocene and a younger one during the Plio-Pleistocene. They suggested, on the basis of palaeomagnetic results from the Ionian islands of Zakynthos, Kefallonia and Corfu, that the western part of the Aegean arc underwent a continuous clockwise rotation during the younger phase, from

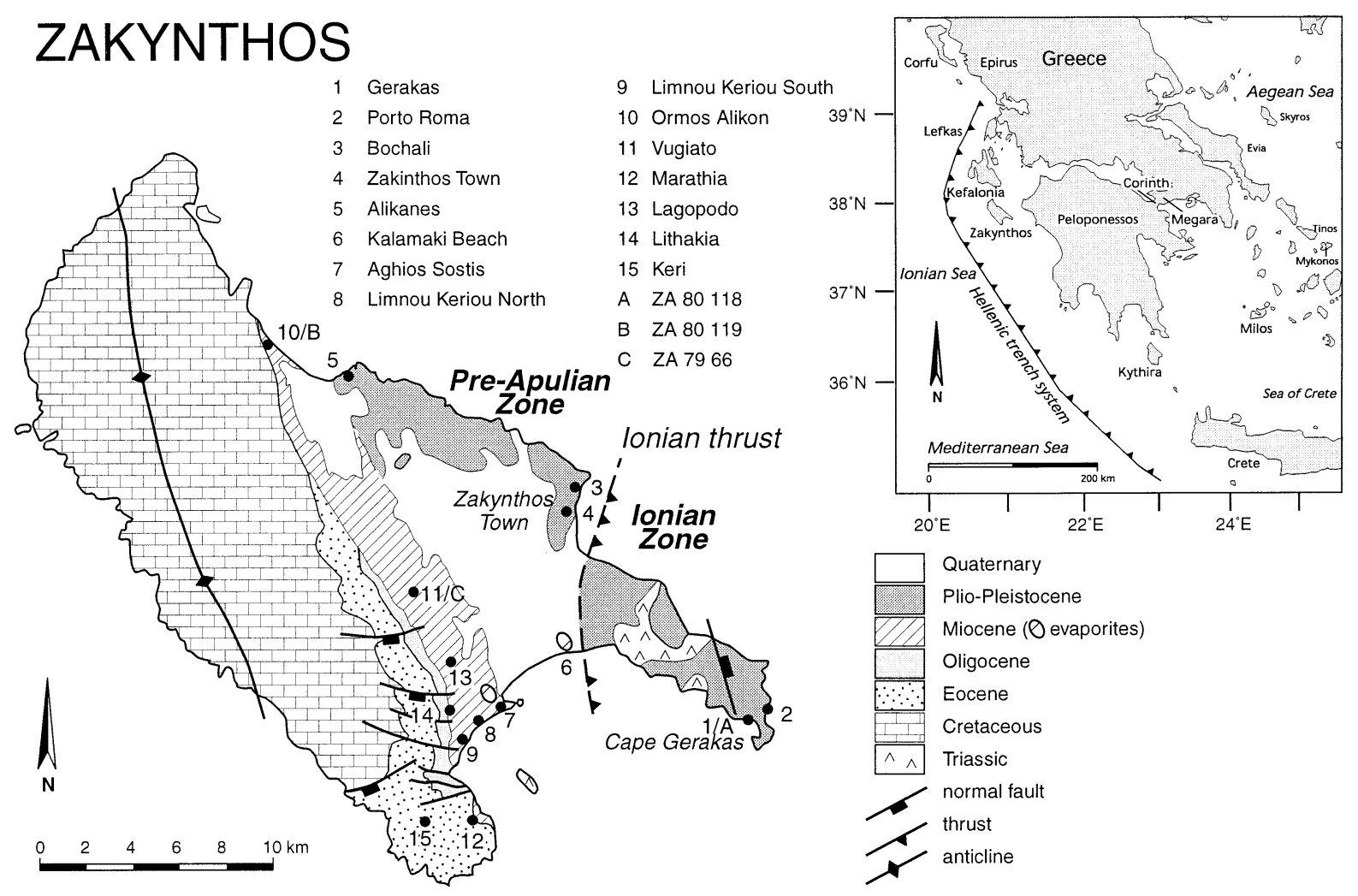

Fig. 1. Location of Zakynthos in the Aegean region. Numbers denote the sampled sections/sites (geological map after Underhill [10]. A, $B$ and $C$ represent sites sampled by Laj et al. [11]. The inset represents the geographical/geological map and the islands discussed in the text. 
approximately $5 \mathrm{Ma}$ to Recent, with an average rate of $5^{\circ} / \mathrm{Ma}$ [11]. The area of clockwise rotations extends further north, including the external Albanides, and ends at the Scutari-Pec transverse zone [13,14]. More to the centre of the Aegean region, on the Cycladic islands of Mykonos [15], Tinos [16], Evia and Skyros [17], comparable clockwise rotations are found. In western Turkey, forming the eastern part of the arc, anticlockwise rotations up to $45^{\circ}$ were identified during the Middle Miocene [12]. Based on palaeomagnetic data from Crete and Rhodes [11,18], it was suggested that the central and eastern parts of the Aegean arc did not rotate since Tortonian respectively Pliocene times. The area of non-rotation (at least since $15 \mathrm{Ma}$ ) extends to the east including the Antalya region in southern Turkey [19]. Many geophysical modelling studies concerning the Aegean arc have used constraints derived from these palaeomagnetic data [20-22]. However, recent results from Crete indicate predominantly post-early Messinian anticlockwise (ac) rotations, in agreement with a tectonostratigraphic analysis [23]. These ac rotations are governed by rotations of fault-bounded blocks. Evidence for anticlockwise rotations in the central Aegean was also found on Naxos since the Middle Miocene [15] and on Milos since the PlioPleistocene [24], constraining the overall sense of rotation in the central part of the Hellenic arc.

Recently, accurate astronomical (polarity) time scales including a significantly improved biostratigraphic resolution [25-27] have allowed to constrain more precisely rotation phases in the central Mediterranean. In contrast to continuous deformation, e.g. as proposed for the western Aegean area, there is increasing evidence for short periods of rapid, pulsed tectonic rotations. For instance, in southern Italy, palaeomagnetic data indicate a large $25^{\circ}$ anticlockwise tectonic rotation phase in Calabria that has taken place somewhere between 8.6 and 7.8 Ma [28]. During the Pliocene, a $10^{\circ}$ clockwise rotation event occurred on Sicily around 3.21 Ma within some 80-100 ka [29], while a Pleistocene rotation phase has been documented in Calabria ( $15^{\circ}$ clockwise) and the southern Apennines ( $23^{\circ}$ anticlockwise) taking place between 0.8 and $0.7 \mathrm{Ma}[30,31]$. For this reason, we decided to examine in detail the timing and duration of tectonic rotations in the western Aegean area. We first selected the island of Zakynthos (Fig. 1) because it contains the most complete sedimentary record of the Ionian islands, with rocks ranging in age from Cretaceous to Pleistocene. The new dating techniques enable to accurately confine the age of the sediments and to determine more precise constraints on rotation phases, and thus on the geodynamics of the Aegean area.

\section{Sections and sampling}

The island of Zakynthos belongs partly to the Ionian and partly to the Pre-Apulian zone (Fig. 1); the latter zone comprises the eastern slope of the African promontory. These two zones are separated by the Ionian thrust, which runs east of Zakynthos town [10] and was emplaced in the Early Pliocene according to Sorel [3].

The sediments on Zakynthos range in age from Cretaceous to Pleistocene and occur in approximately parallel, linear zones running NW-SE (Fig. 1). A mountain belt, formed by Cretaceous limestones, dominates the western part of the island, the pre-Apulian zone. To the east, we encounter rhythmically bedded Eocene deposits, followed by Oligocene olistostromes embedded in Miocene (Aquitanian to Serravallian) pelagic limestones. Scattered outcrops of Tortonian age mainly consist of alternations of marls and sapropels. The southern part of Zakynthos encompasses a long and continuous Messinian section of marls and sandy turbidites, which at the top abruptly pass into steeply dipping $\left(\sim 60^{\circ}\right)$ evaporites related to the Messinian salinity crisis. These evaporites are overlain by Pliocene 'Trubi'-like marls, representing the basal Zanclean flooding of the Mediterranean. Younger Pliocene sediments are found along the northeast coast of the island and at the base of the 'Citadel section' near Zakynthos town. This section has previously been subjected to detailed studies as it contains the Plio-Pleistocene boundary $[32,33]$. The Pliocene part consists of alternating clays and silt/sandstones with some sapropelitic intercalations in the lower part; the sand content is increasing towards the top. The Pleistocene part (Citadel-Bochali sequence) consists of an alternation of open marine turbidites, which in turn are overlain by calcarenites.

The southeastern peninsula of Zakynthos is believed to belong to the Ionian zone and is pre- 
dominantly formed by Triassic evaporites and PlioPleistocene sediments [10]. This part is separated from the Apulian zone by an area of intense deformation. Diapirism of Triassic evaporites, large-scale faulting and thrusting resulted in scattered and highly deformed outcrops of sediments in the western part of this peninsula. The southeastern part of the Ionian zone at Cape Gerakas contains well-exposed sections of Pliocene-Pleistocene marls, but clear signs of deformation (steeply $\left(\sim 40^{\circ}\right)$ dipping layers, folding and normal faulting) caused by Late Pliocene to Quaternary diapiric intrusion, are observed [34]. These marls, immediately adjacent to the diapirs in SE Zakynthos, are steeply dipping and overturned ([34], field observations), and are overlain by an undeformed series of Pleistocene marls alternating with calcareous sandstones/calcarenites [35], resembling the earlier mentioned Citadel-Bochali sequence. A detailed stratigraphic study also revealed the PlioPleistocene boundary in this area [36].

For our study, fifteen sites and sections have been selected all over Zakynthos with ages ranging from Eocene to Pleistocene. All but two sections/sites consist of undeformed sediments with (slightly) inclined strata. The Messinian marls and evaporites at Kalamaki Beach and the Plio-Pleistocene marls at Cape Gerakas (one of the sites of Laj et al. [11]) were sampled despite their signs of deformation. We have also sampled the two other sites on Zakynthos (Fig. 1) used by Laj et al. [11]. A total of 609 cores was sampled and drilled with an electrical drill and generator. Preferentially, continuous sections were sampled - with three cores per level (for paleomagnetic, biostratigraphic and rock magnetic analysis) - formed by outcrops of more than $10 \mathrm{~m}$ stratigraphic thickness. This allows magnetostratigraphy to be used as an age constraint in addition to the detailed biostratigraphy. Individual outcrops were sampled with eight to fourteen cores per site. Mostly, fine-grained sediments (clays, marls) were sampled with a low sedimentation rate (typically $5 \mathrm{~cm} / \mathrm{ka}$ ) and over a sufficiently large interval, thus averaging out, to a large extent, secular variation. In addition, early post-depositional processes typically smooth out the finer-scale variations of the geomagnetic field [37].

Ages of sections are mainly obtained by recording foraminiferal and calcareous nannofossil species (caption to Fig. 2) of which last (common) occurrences $(\mathrm{L}(\mathrm{C}) \mathrm{O})$ and first (common) occurrences $(\mathrm{F}(\mathrm{C}) \mathrm{O})$ have been dated. Foraminifers have been analysed in washed residues of $>125 \mu \mathrm{m}$; for calcareous nannofossils we have used smearslides. The sections/sites including the age diagnostic species are shown in Fig. 2 and described in Appendix A together with their Mediterranean chronostratigraphy and numerical ages [25,27,42]. Most sections have additional magnetostratigraphic constraints (Appendix A).

\section{Palaeomagnetic results}

\subsection{Analysis of the natural remanent magnetisation (NRM) and isothermal remanent magnetisation (IRM)}

The natural remanent magnetisation (NRM) was measured on a $2 \mathrm{G}$ Enterprise DC SQUID cryogenic magnetometer using progressive stepwise thermal demagnetisation with temperature increments of 30 or $50^{\circ} \mathrm{C}$, from room-temperature to the limit of reproducible results. The demagnetisation results (Figs. 3 and 4) show that often a small viscous and laboratory-induced component is removed at $100^{\circ} \mathrm{C}$, while occasionally a relatively small secondary present-day field component exists which is typically removed at $\sim 200^{\circ} \mathrm{C}$. As a rule, steps below $\sim 200^{\circ} \mathrm{C}$ are never used to determine characteristic components because of possible overlap of blocking temperature spectra (e.g. Fig. 3b). Demagnetisation at temperatures higher than $200^{\circ} \mathrm{C}$ reveals two types of demagnetisation behaviour related to intensities and different maximum unblocking temperatures. In general, samples with a relatively low NRM intensity have a characteristic remanent magnetisation (ChRM) which is completely removed at $360-400^{\circ} \mathrm{C}$ (Fig. 3d,f,i and Fig. 4a-h). Demagnetisation at temperatures higher than $360-390^{\circ} \mathrm{C}$ results in randomly directed magnetisations because of alteration (oxidation) of iron sulphides (typically pyrite), which is commonly observed in this type of marls and clays. In high NRM intensity samples the ChRM is usually only completely removed at $580-620^{\circ} \mathrm{C}$ (Fig. $3 \mathrm{a}-\mathrm{c}, \mathrm{e}, \mathrm{g}, \mathrm{h}$ and Fig. 4i), but also here disturbing magnetisations may occur at temperatures above $360-390^{\circ} \mathrm{C}$, depending 


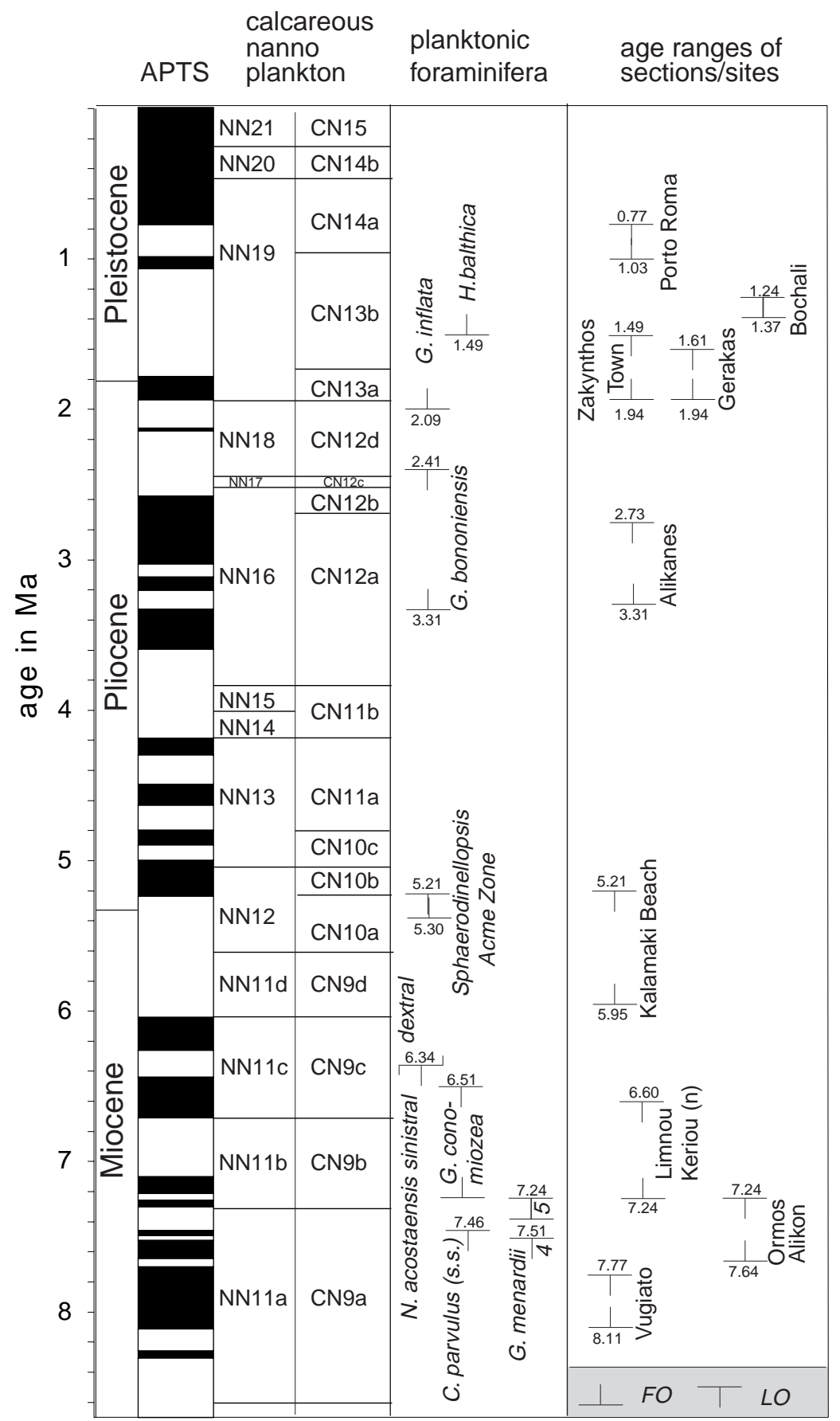

Fig. 2. Astronomical polarity time scale (APTS) of Lourens et al. [27] for the Pliocene and Hilgen et al. [25] and Krijgsman et al. [38] for the Miocene with calcareous nannoplankton zones [39,40] and planktonic foraminifera [25-27,41] biochronology. $F O(L O)$ indicates first (last) occurrences and s.s. small sized. The sections/sites from Zakynthos are correlated on the basis of magnetostratigraphy, planktonic foraminifera, calcareous nannoplankton and polarities. For details see Appendix A. 
Miocene

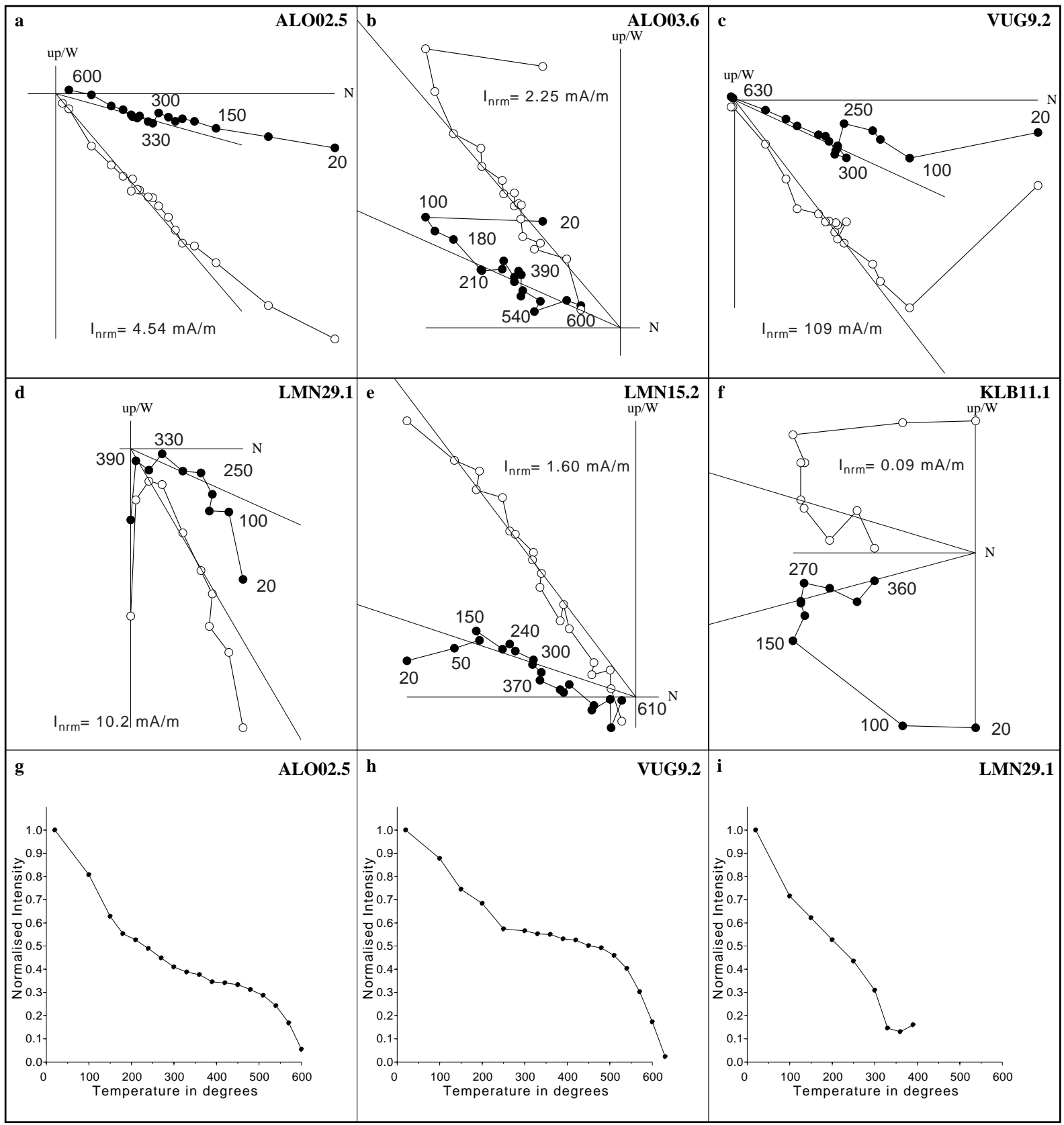

Fig. 3. Orthogonal projections of stepwise thermal demagnetisation diagrams (corrected for bedding tilt) from Miocene sediments on Zakynthos. Closed (open) circles represent the projection of the NRM vector endpoint on the horizontal (vertical) plane. Values denote demagnetisation steps in ${ }^{\circ} \mathrm{C}$. Codes can be found in Table 1; line represents the interpreted result. The initial NRM intensities $\left(I_{\text {nrm }}\right)$ are given. Some normalised intensity plots are also given $(\mathrm{g}-\mathrm{i})$. 
Pliocene-Pleistocene

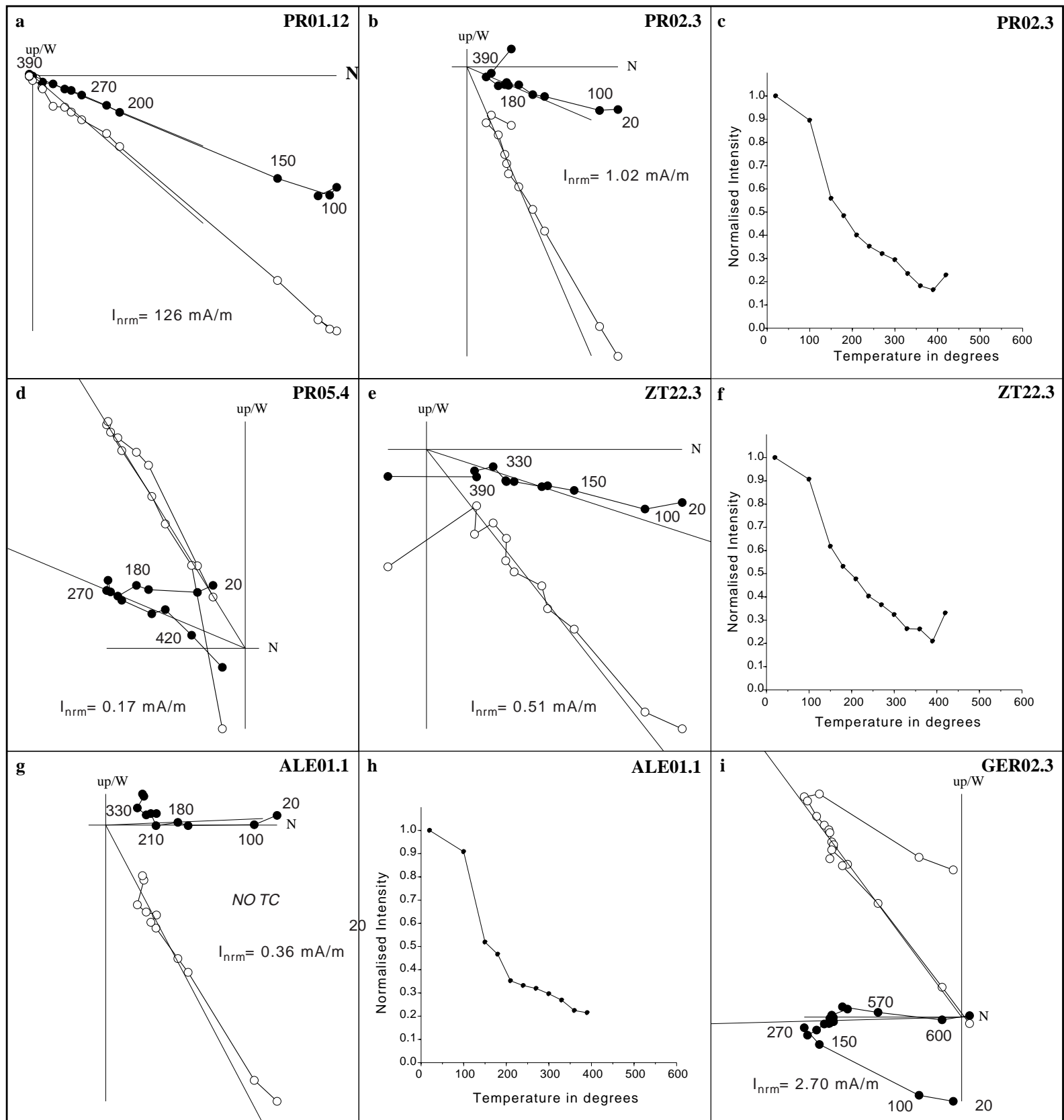

Fig. 4. Orthogonal projections of stepwise demagnetisation diagrams (corrected for bedding tilt) from Plio-Pleistocene sediments on Zakynthos. See also caption to Fig. 2; no tc (g) means without tectonic tilt correction. Some normalised intensity plots are also given (c, f, h).

on the presence of iron sulphides. Since this may cause an apparent decay of the ChRM passing the origin (e.g. Fig. 3e), we have in such cases conser- vatively used only the data points below $\sim 390^{\circ} \mathrm{C}$. Samples with a large present-day overprint or unstable samples were not used. As the outcrops are 
monoclinal, the fold-test could not be performed. The reversal-test was positive for Ormos Alikon and Limnou Keriou (Classifications B and C, respectively). For the Porto Roma site the reversal test was negative, but this is commonly observed in these types of sediments [43]. Although Scheepers and Langereis [44] devised a method to correct the nonantipodality between normal and reversed polarity, it appears that simply averaging normal and reversed directions yields essentially the same result.

We performed some rock magnetic tests to identify the dominant carriers of the remanence, including acquisition of a three-component [45] isothermal remanent magnetisation (IRM) and subsequent demagnetisation of this IRM. The IRM was induced in a pulse magnetiser and was measured on a digitised spinner magnetometer based on a Jelinek JR3 driver unit. The IRM was induced in three orthogonal directions using fields of $75 \mathrm{mT}, 200 \mathrm{mT}$ and $2 \mathrm{~T}$. All samples, both normal and reversed, are characterised by the dominance of a low-coercivity mineral (Fig. 5A,B) and the magnetisation is carried by magnetic minerals with coercivities below $200 \mathrm{mT}$, mostly below $75 \mathrm{mT}$ (Fig. 5C,D). The relatively lowintensity samples $(0.2-0.8 \mathrm{~mA} / \mathrm{m})$ show a maximum blocking temperature around $570^{\circ} \mathrm{C}$, indicating the presence of magnetite, but iron sulphides are likely present as well as can be seen from the inflexion at $\sim 350^{\circ} \mathrm{C}$ (Fig. 5C,D). The ChRM in these low-intensity samples was removed at $360-400^{\circ} \mathrm{C}$; the $\mathrm{ChRM}$ at higher temperatures could not be measured. The relatively high-intensity samples $(3-55 \mathrm{~mA} / \mathrm{m})$ have a maximum blocking temperature between 600 and $650^{\circ} \mathrm{C}$, suggesting (partly) oxidised magnetite as the dominant carrier of the NRM (Fig. 5D).

The characteristic directions of the magnetisations were determined by least squares fitting (principal component analysis) through selected data points. For each section or site, average ChRM-directions were calculated using Fisher statistics (Fig. 6; Table 1). The distribution of the ChRM directions on Zakynthos can be seen in Fig. 7; the errors are calculated using $R / \Delta R$ and $F / \Delta F$ (Table 1). Directions before and after tilt corrections have essentially the same precision parameter $(k)$; low $k$ values are typically seen in low-intensity samples.

\section{Discussion}

Our palaeomagnetic data of all sampled late Neogene sections on Zakynthos, in both the pre-Apulian and Ionian zones, show no significant differences in rotation. Since the ages of the sediments range from Tortonian (8.11 Ma) to Pleistocene (1.03-0.77 Ma), it must be concluded that no differential rotations took place between $8.11 \mathrm{Ma}$ and $0.77 \mathrm{Ma}$. Thus, the overall $22^{\circ}$ clockwise rotation (Table 1) must have occurred since $0.77 \mathrm{Ma}$.

The results of three sites, however, are questionable. The Alikanes section shows magnetisations largely removed at low $\left(200^{\circ} \mathrm{C}\right)$ temperatures and is a classic example of overprinting, which is confirmed by the present-day field direction before tilt correction (Fig. 6e; Table 1). At Gerakas, the marls are steeply dipping and overturned caused by Late Pliocene to Quaternary diapirism [34]. Although the large error makes the small clockwise rotation of Gerakas not incompatible with other results (Table 1), we feel that including this result is not warranted. At Kalamaki Beach, the (late) Messinian evaporites reveal anticlockwise rotations. Because of the observed deformation in these evaporites in the vicinity of the Ionian thrust, we do not regard this result as representative. Therefore, we prefer not to include the results from Alikanes, Cape Gerakas and Kalamaki Beach.

Our new results have considerable implications for the geodynamic evolution of the western Aegean arc. A previous tectonic reconstruction for the northwestern part of Greece was made by Kissel and Laj [12], based on combined palaeomagnetic data from the Ionian islands of Zakynthos, Kefallonia and Corfu. They suggested that all three islands were subjected to a continuous rotation starting at $5 \mathrm{Ma}$, with an average rate of $5^{\circ} / \mathrm{Ma}$. This scenario was predominantly based on (9) results from Corfu, whereas fewer results were obtained from Zakynthos (3) and from Kefallonia (4). Kissel and Laj [12] thus considered the Ionian islands as a structural unity, and they argued that this is supported by structural data from Mercier et al. [46].

We sampled the Laj et al. [11] sites from Zakynthos and re-dated them. It appears that our ages of these sites are significantly younger. The reason for this difference cannot be determined because no age diagnostic fossils are given in Laj et al. [11]. 
(A)

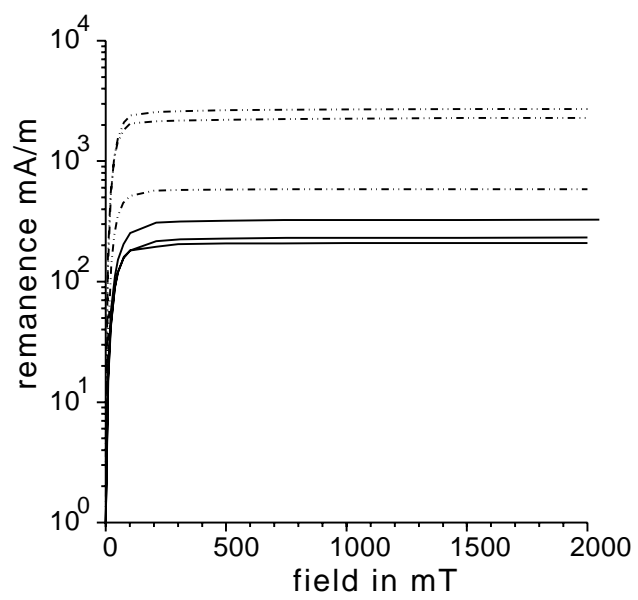

(B)

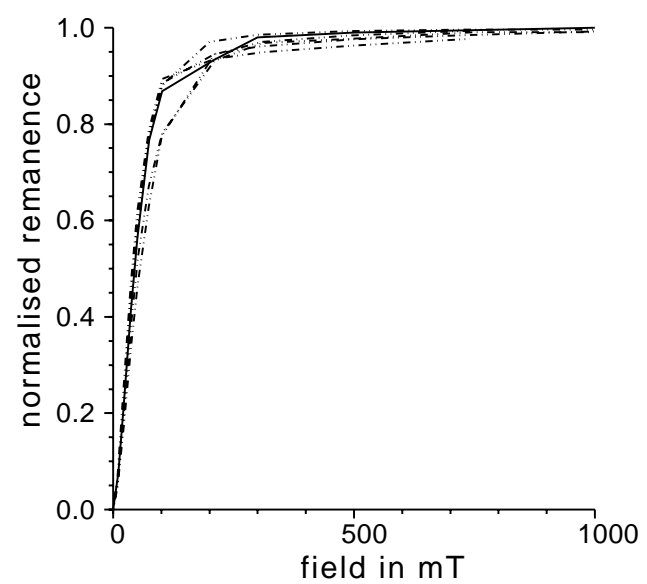

(C)

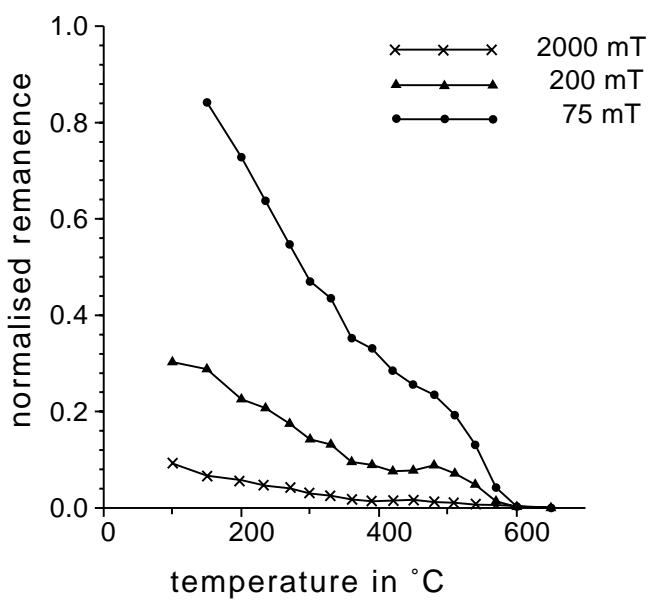

\section{IRM Demagnetisation}

(D)

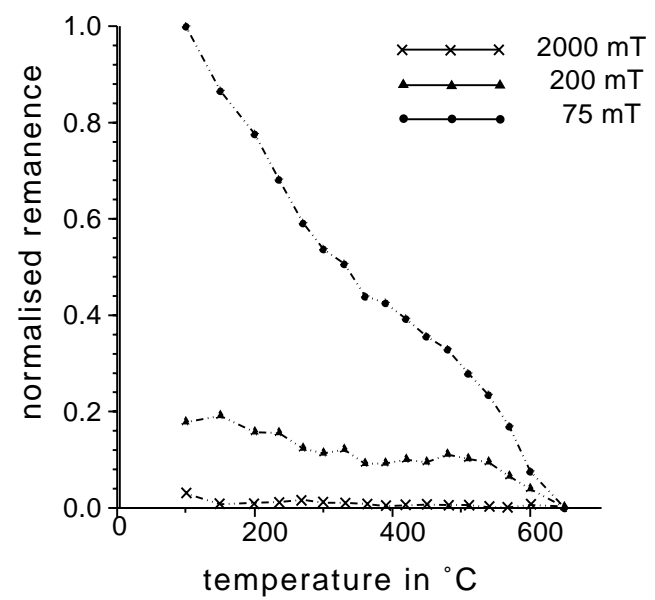

Fig. 5. Examples of absolute (A) and normalised (B) IRM acquisition of samples from Zakynthos. Solid (dotted) lines represent relatively low- (high-) intensity samples. Stepwise thermal demagnetisation of the normalised three-component IRM of a low- (C) and high- (D) intensity sample indicates magnetite, respectively maghemite as the main carriers of the ChRM.

Our larger number of sample localities and accurate age constraints clearly reveal a different tectonic evolution at least for the island of Zakynthos. A continuous rotation during the last $5 \mathrm{Ma}$ seems no longer tenable, since our new palaeomagnetic data indicate that a significant clockwise rotation of $\sim 22^{\circ}$ occurred between $0.77 \mathrm{Ma}$ and the Recent, while no rotational motions occurred between at least 8.11 and 0.77 Ma (Fig. 8). Our different geodynamic scenario for Zakynthos need not be surprising, because Zakynthos (and Kefallonia) are separated from Corfu by the important Kefallonia Fault Zone. Moreover, Corfu does not overlie the Hellenic subduction zone, in contrast to Zakynthos and Kefallonia. It may thus have experienced a tectonic evolution quite different from that of Zakynthos. Although the rotation 
Table 1

Results from NRM analysis from the different sections on Zakynthos

\begin{tabular}{|c|c|c|c|c|c|c|c|c|c|c|c|c|c|c|c|c|}
\hline Site/Section & CODE & $N$ & $\begin{array}{l}D_{\text {notc }} \\
\left({ }^{\circ}\right)\end{array}$ & $\begin{array}{l}I_{\text {notc }} \\
\left({ }^{\circ}\right)\end{array}$ & $k$ & $\begin{array}{l}\alpha_{95} \\
\left({ }^{\circ}\right)\end{array}$ & $\begin{array}{l}D_{\mathrm{tc}} \\
\left({ }^{\circ}\right)\end{array}$ & $\begin{array}{l}I_{\mathrm{tc}} \\
\left({ }^{\circ}\right)\end{array}$ & $k$ & $\begin{array}{l}\alpha_{95} \\
\left({ }^{\circ}\right)\end{array}$ & $\begin{array}{l}\text { rot. } \\
\left({ }^{\circ}\right)\end{array}$ & $\begin{array}{l}R \\
\left({ }^{\circ}\right)\end{array}$ & $\begin{array}{l}\Delta R \\
\left({ }^{\circ}\right)\end{array}$ & $\begin{array}{l}F \\
\left({ }^{\circ}\right)\end{array}$ & $\begin{array}{l}\Delta F \\
\left({ }^{\circ}\right)\end{array}$ & $\begin{array}{l}\text { Age } \\
\text { (Ma) }\end{array}$ \\
\hline Porto Roma ${ }^{1}$ & PR & 20 & 12.1 & 62.0 & 135.7 & 2.8 & 20.0 & 59.2 & 98.4 & 3.3 & $20 \mathrm{c}$ & 14.5 & 5.6 & -6.1 & 3.2 & $1.03-0.77$ \\
\hline Bochali $^{1}$ & BOC & 8 & 193.5 & -58.2 & 65.3 & 6.9 & 199.5 & -50.2 & 65.3 & 6.9 & $20 \mathrm{c}$ & 14.0 & 8.9 & 2.9 & 5.8 & $1.37-1.24$ \\
\hline Zakynthos Town ${ }^{1}$ & $\mathrm{ZT}$ & 41 & 21.8 & 63.8 & 43.2 & 3.4 & 22.3 & 54.5 & 43.6 & 3.4 & $22 \mathrm{c}$ & 16.8 & 5.1 & -1.4 & 3.3 & $1.94-1.44$ \\
\hline Gerakas & GER & 8 & 137.2 & -55.2 & 12.9 & 16.0 & 187.9 & -54.1 & 20.9 & 12.4 & $8 \mathrm{c}$ & 2.4 & 17.3 & -1.0 & 10.1 & $1.94-1.61$ \\
\hline ZA $80118^{*}$ & A & 10 & - & - & - & - & 184.0 & -57.0 & 84.5 & 4.8 & $4 \mathrm{c}$ & -1.5 & 7.4 & -3.9 & 4.3 & $1.8-1.61$ \\
\hline Alikanes & ALE & 18 & 358.7 & 55.0 & 225.2 & 2.3 & 341.5 & 58.9 & 204.3 & 2.4 & - & -6.8 & 3.8 & -1.9 & 2.6 & $3.31-2.73$ \\
\hline Kalamaki Beach & KLB & 11 & 143.2 & -19.3 & 27.3 & 8.9 & 169.2 & -22.6 & 27.3 & 8.9 & $11 \mathrm{ac}$ & -16.3 & 8.0 & 30.5 & 7.4 & $5.95-5.21$ \\
\hline Aghios Sostis & SOS & 9 & - & - & - & - & - & - & - & - & - & - & - & - & - & Messinian \\
\hline Limnou Keriou (north) ${ }^{2}$ & $\mathrm{LMN}$ & 23 & 176.4 & -58.2 & 44.9 & 4.6 & 199.2 & -47.4 & 47.7 & 4.4 & $19 \mathrm{c}$ & 13.7 & 5.6 & 5.7 & 4.0 & $7.24-6.60$ \\
\hline Linmou Keriou (south) & LMS & 4 & - & - & - & - & - & - & - & - & - & - & - & - & - & Tortonian \\
\hline Ormos Alikon ${ }^{2}$ & ALO & 25 & 170.6 & -58 & 30.1 & 5.4 & 195.1 & -40.5 & 34.1 & 5.0 & $15 \mathrm{c}$ & 9.6 & 5.7 & 12.6 & 4.4 & $7.64-7.24$ \\
\hline ZA $80119^{*}$ & $\mathrm{~B}$ & 7 & - & - & - & - & 206.8 & -39.8 & 248.0 & 3.5 & $27 \mathrm{c}$ & 21.3 & 4.2 & 13.3 & 3.3 & $7.64-7.24$ \\
\hline Vugiato $^{2}$ & VUG & 14 & 350.3 & 70.2 & 22.3 & 8.6 & 23.9 & 50.3 & 20.9 & 8.9 & $24 \mathrm{c}$ & 18.4 & 11.4 & 2.8 & 7.4 & $8.11-7.70$ \\
\hline ZA $7966^{*}$ & $\mathrm{C}$ & 15 & - & - & - & - & 25.3 & 44.9 & 76.6 & 4.1 & $25 \mathrm{c}$ & 19.8 & 5.1 & 8.2 & 3.8 & $8.11-7.70$ \\
\hline Marathia & MA & 8 & - & - & - & - & - & - & - & - & - & - & - & - & - & Serravalian \\
\hline Lagopodo & LAG & 20 & - & - & - & - & - & - & - & - & - & - & - & - & - & early Middle Miocene \\
\hline Lithakia & LIT & 7 & - & - & - & - & - & - & - & - & - & - & - & - & - & early Middle Miocene \\
\hline Keri & $\mathrm{KE}$ & 7 & - & - & - & - & - & - & - & - & - & - & - & - & - & Eocene \\
\hline \multicolumn{17}{|l|}{ Mean } \\
\hline${ }^{1}$ Pleistocene & & 3 & - & - & - & - & 20.6 & 54.6 & 312.4 & 7.0 & $21 \mathrm{c}$ & 15.1 & 9.9 & -1.5 & 5.9 & $1.94-0.77$ \\
\hline${ }^{2}$ Miocene & & 3 & - & - & - & - & 19.1 & 46.1 & 189.5 & 9.0 & $19 \mathrm{c}$ & 13.6 & 10.6 & 7.0 & 7.4 & $8.11-6.60$ \\
\hline All & & 8 & - & - & - & - & 21.6 & 48.4 & 128.0 & 4.9 & $22 \mathrm{c}$ & 16.1 & 6.3 & 4.7 & 4.3 & $8.11-0.77$ \\
\hline
\end{tabular}

*Laj et al. [11] (redated).

Corrected and uncorrected for bedding tilt; ages are indicated. $N=$ number of specimens; $D, I=$ site mean ChRM declination and inclination; $k=$ Fisher's precision parameter; $\alpha_{95}=95 \%$ cone of confidence; rot. $=$ sense of rotation, (a)c $=\left(\right.$ anti)clockwise with a $0^{\circ}$ reference direction; $\alpha_{95} / \cos (I)=\operatorname{error}($ see Fig. 6$)$. 
a. Porto Roma

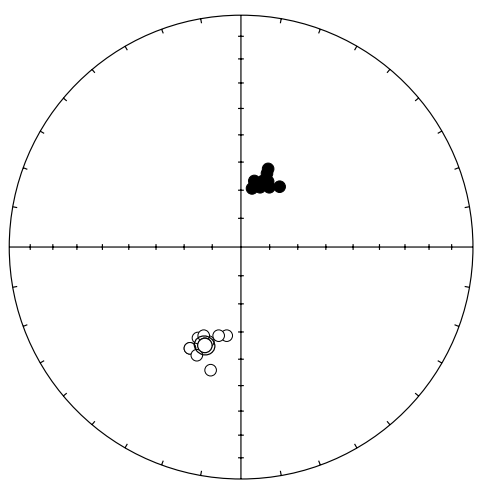

d. Gerakas

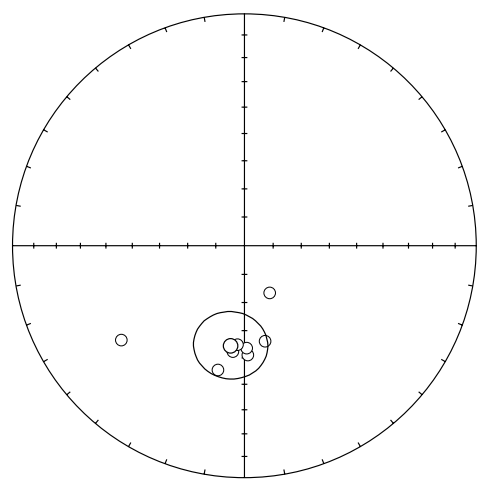

g. Limnou Keriou

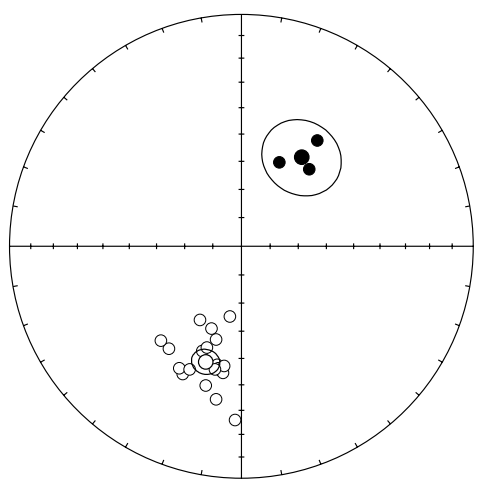

b. Bochali

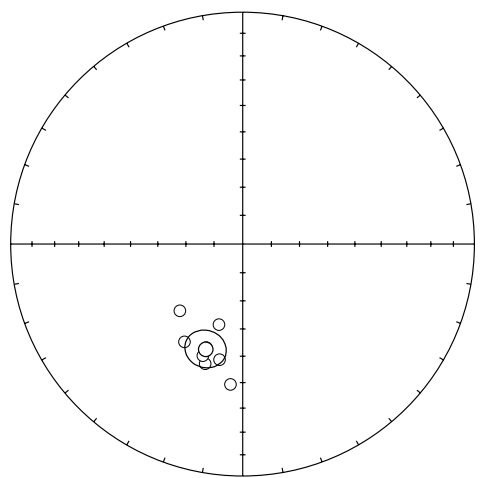

e. Alikanes

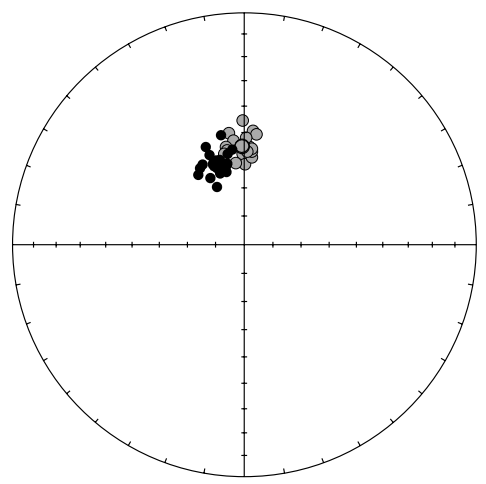

h. Vugiato

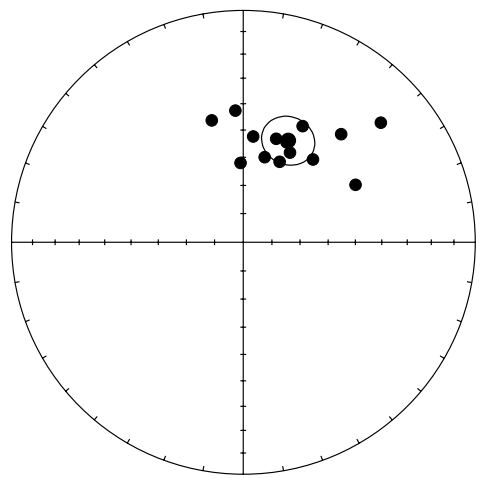

c. Zakinthos Town

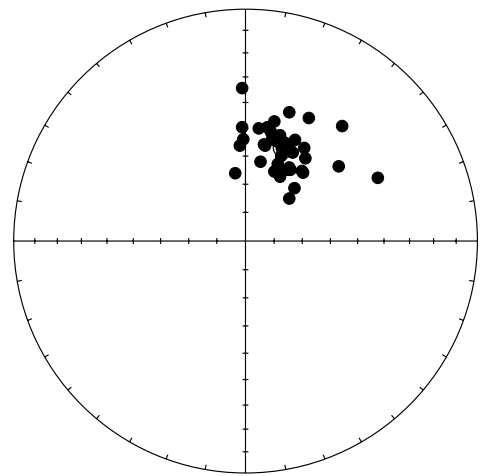

f. Kalamaki Beach

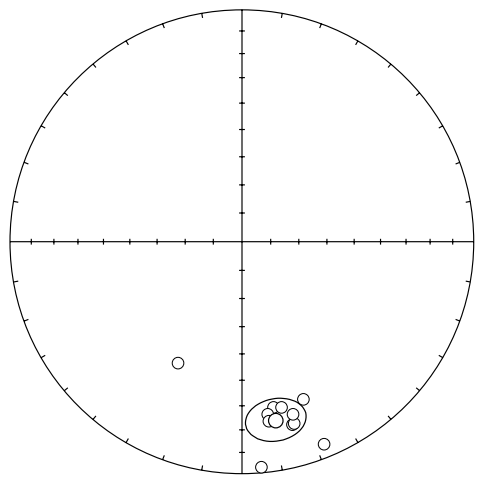

i. Ormos Alikon

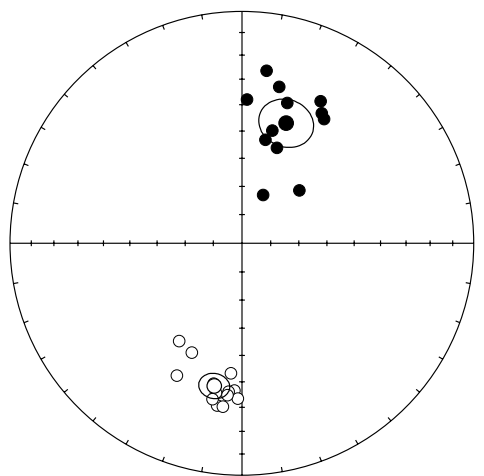

Fig. 6. Equal-area projections of the ChRM from Mio/Plio and Pleistocene sections on Zakynthos, corrected for bedding planes. Closed (open) circles represent downward (upward) projections. Ellipses denote $\alpha_{95}$. The grey circles (Alikanes) indicate the ChRM results before bedding plane correction and are indistinguishable from the present-day field direction. 


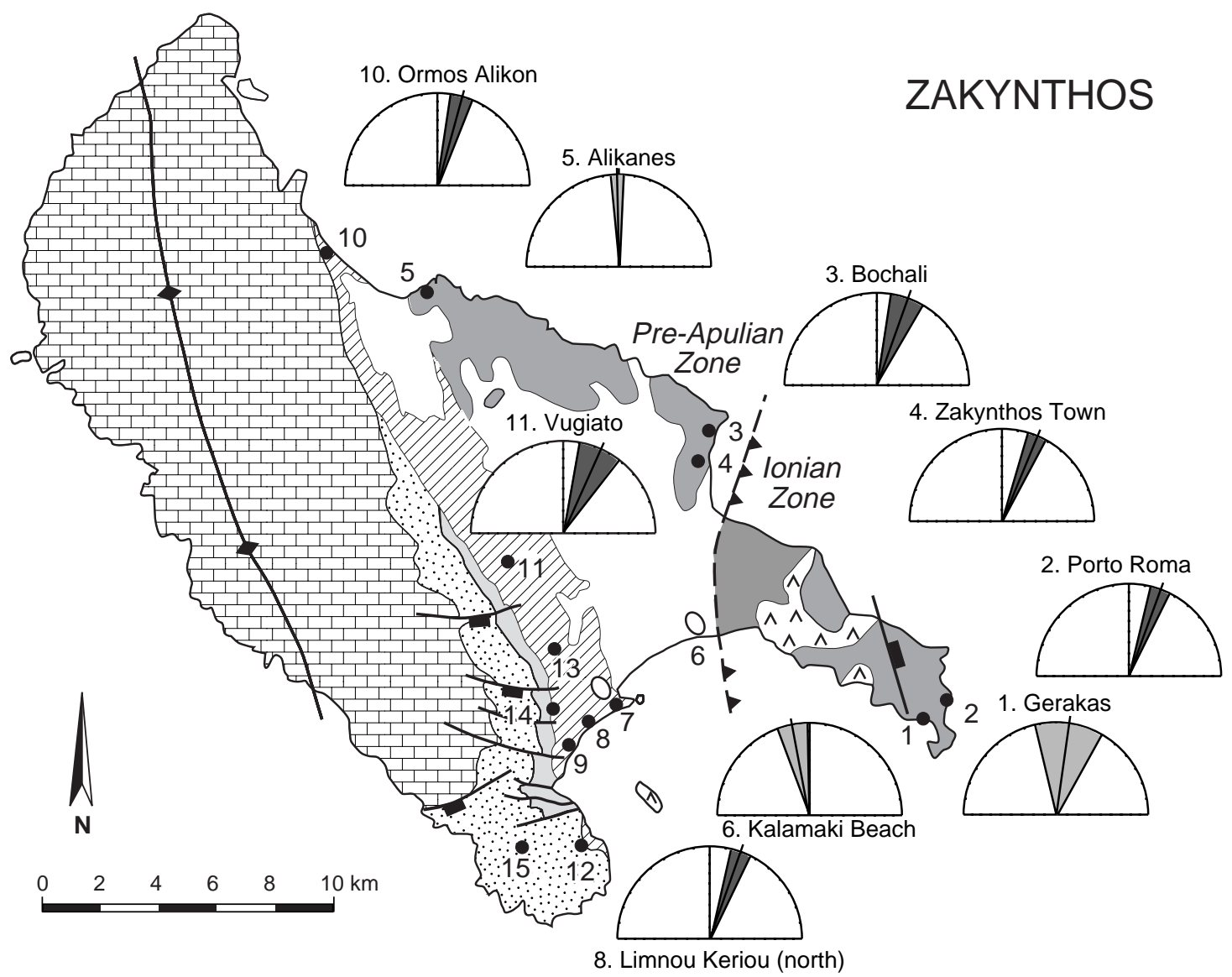

Fig. 7. Locality mean ChRM declinations on Zakynthos; shaded segment represents the statistical error $\alpha_{95} / \cos (I)$ (Table 1). See also caption to Fig. 1.

phase might have been influenced by local tectonics, considerable evidence is present suggesting a more regional cause, as outlined below.

The tomographic studies of Spakman [4] have shown that the African slab (Adria) is subducting in the west underneath Italy, and in the east underneath Greece. These studies have also shown that the African slab is detached both underneath Calabria in southern Italy and beneath the southern Peloponessos in Greece [47]. After slab detachment, rebound processes can cause rapid uplift in the internal zones caused by stretching of the shallow remainder of the slab [48]. This scenario is used by Sorel et al. [49] to explain the Pleistocene uplift of the Ionian islands, and which consequently would date the detachment in the Ionian region at that period [4]. In addition, much of the relief of southern Greece has developed only in the last million years [50]. As detachment proceeds, the gravitational pull of the detached part of the slab is transferred to the undetached part. This leads to an increase in the effective slab pull exerted by the undetached slab. A more pronounced outward migration of the trench, relative to the situation where only the roll-back process is active, is expected above the undetached slab [48] which then may result in rotations.

Furthermore, detailed studies of present-day and past stress fields in the Aegean [20] revealed a temporal change in the orientation of tensional stress from NE-SW to NNW-SSE in the northern Aegean region - during the Late Pleistocene (post-Calabrian and pre-Milazzian) [51], i.e. roughly between 0.8 and $0.3 \mathrm{Ma}$. Numerical modelling of stress patterns by Meijer and Wortel [52] indicated that this change in orientation is likely caused by lateral mi- 


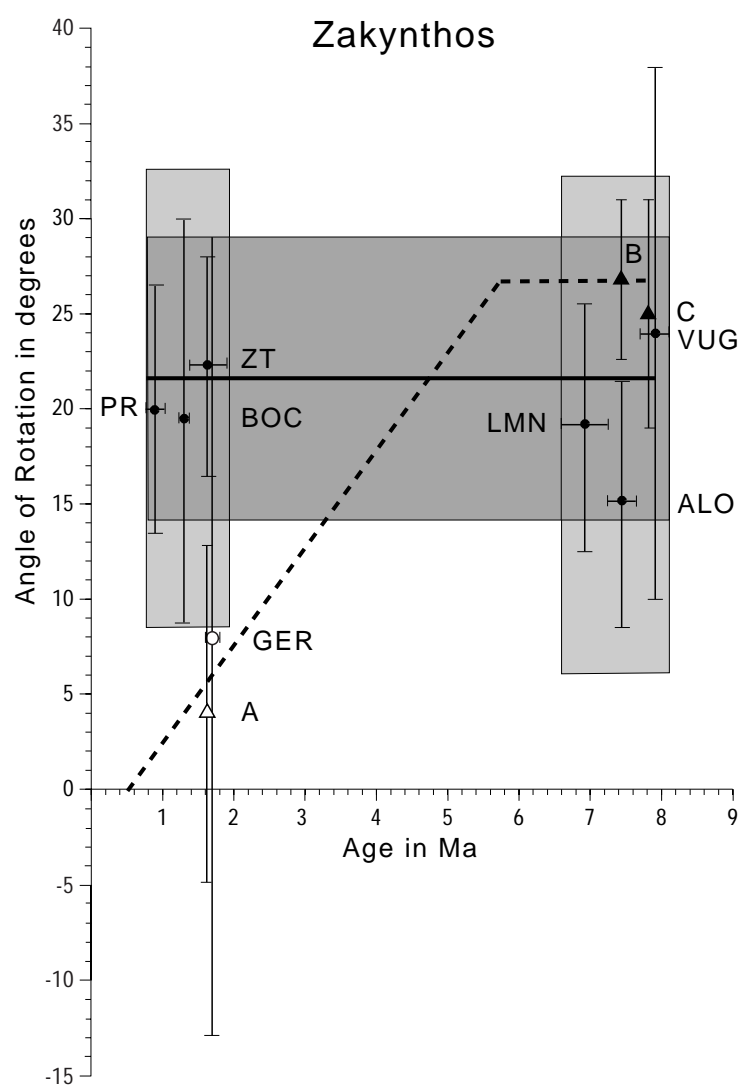

Fig. 8. Locality mean ChRM declination versus age on Zakynthos; codes are according to Table 1. Closed symbols indicate reliable results, open symbols are disregarded (see text for discussion). Circles are derived from this study, triangles from Laj et al. [11]. Vertical bars indicate error $\left(\alpha_{95} / \cos (I)\right)$, horizontal bars denote age range. Light shaded rectangles give $\alpha_{95} / \cos (I)$ of Miocene and Pleistocene localities. The thick line and the dark shaded rectangle shows the mean rotation and the error $\alpha_{95} / \cos (I)$. Dotted thick line is the interpretation of Laj et al. [11] for the Ionian islands, indicating $5^{\circ} / \mathrm{Ma}$ starting around $5 \mathrm{Ma}$.

gration of slab detachment [6] on the eastern side of Adria. Our clockwise rotation phase on Zakynthos occurred after $0.77 \mathrm{Ma}$, corresponding to this change in stress regime. Hence, we prefer a scenario in which slab detachment and the subsequent rebound causes uplift and a change in stress regime, which in turn causes rotations.

The Pleistocene rotational phase on Zakynthos appears to have been rapid since it must have taken place some time during the last 0.77 Ma. A similar young and rapid Pleistocene tectonic rotation phase was found in southern Italy. In Calabria, the Calabro-Peloritan block underwent a $15^{\circ}$ clockwise rotation between 0.8 and $0.7 \mathrm{Ma}$ [31], whereas the southern Apennines experienced a time-equivalent $23^{\circ}$ anticlockwise rotation [30,31]. Concurrently (0.9-0.7 Ma), uplift in Calabria (southern Italy) occurred which Westaway [53] related to slab detachment. Thus it appears that on both sides of the Adriatic platform a similar process of slab detachment, rebound, uplift and tectonic rotations occurred.

\section{Conclusions}

Our palaeomagnetic data show that during the last $8 \mathrm{Ma}$, the geodynamic evolution of the Ionian island of Zakynthos is marked by no significant rotational movements during Tortonian $(8.11 \mathrm{Ma})$ to Pleistocene $(0.77 \mathrm{Ma})$ times. A well-defined and rapid tectonic event occurs younger than $0.77 \mathrm{Ma}$ causing a $22^{\circ}$ clockwise rotation of the island. The Early Pliocene emplacement of the Ionian thrust did not result in any differential rotations of the island.

We link the clockwise rotation of Zakynthos to Late Pleistocene uplift in (mainland) Greece [50], related to rebound processes resulting from (African) slab detachment underneath the Ionian islands [6,52]. A similar process of slab detachment, rebound, uplift, and subsequent rotations is also found in southern Italy. This implies that rotations may ultimately be linked to slab detachment.

\section{Acknowledgements}

We thank Frits Hilgen, Paul Meijer, Piet-Jan Verplak, Henk Meijer, Sander Ernst, Sander van Heijst, Jeroen Keur, Iwan de Lugt, Lennert Pronk, Mark Sier, Bas West, Gerrit in 't Veld and Geert Ittmann for their discussions, help in the field and in the lab. We also thank an anonymous reviewer, Fabio Speranza, Rob Westaway, Hagai Ron and Catherine Kissel for their comments. The I.G.M.E. is thanked for providing the necessary working permission. Finally, Anastasia and Spiros Lougaris of the Castelli Hotel in Laganas made our stay on Zakynthos very pleasant. This work was conducted under the programme of the Vening Meinesz research School of Geodynamics (VMSG). [R $\boldsymbol{V}]$ 


\section{Appendix A}

\section{Lithakia}

Age:

Geographical coordinates:

Lithology:

Cores:

Fossil content:

Magnetostratigraphy:

Lagopodo

Age:

Geographical coordinates:

Lithology:

Cores:

Fossil content:

Magnetostratigraphy:

Marathia

Age:

Geographical coordinates:

Lithology:

Cores:

Fossil content:

Magnetostratigraphy:

Vugiato $(=$ ZA 7966$)$

Age:

Geographical coordinates:

Lithology:

Cores:

Fossil content:

Magnetostratigraphy:

Ormos Alikon (=ZA 80 119)

Age:

Geographical coordinates:

Lithology:

Fossil content:

Magnetostratigraphy:

Limnou Keriou South

Age:

Geographical coordinates:

Lithology:

Cores:

Fossil content:

Magnetostratigraphy:

Limnou Keriou North

Age:

Geographical coordinates:

Lithology:

Cores:

Fossil content:

Magnetostratigraphy: late Early to early Middle Miocene

$37^{\circ} 42^{\prime} \mathrm{N} / 20^{\circ} 49^{\prime} \mathrm{E}$

blue laminated limestones

3 sites $/ 26$ cores

$H$. ampliaperta and $H$. heteromorphus (pre-Orbulina age)

undetermined

late Early to early Middle Miocene

$37^{\circ} 44^{\prime} \mathrm{N} / 20^{\circ} 47^{\prime} \mathrm{E}$

scattered outcrops of laminated limestones/marls

5 sites/39 cores in marls

H. ampliaperta and H. heteromorphus (pre-Orbulina age)

undetermined

Serravalian

$37^{\circ} 40^{\prime} \mathrm{N} / 20^{\circ} 51^{\prime} \mathrm{E}$

$\sim 30$ m blue marls

4 sites/32 cores in marls

$H$. walbersdorfensis and $H$. orientalis

undetermined

8.11-7.77 Ma

$37^{\circ} 46^{\prime} \mathrm{N} / 20^{\circ} 46^{\prime} \mathrm{E}$

$25 \mathrm{~m}$ clays with 16 intercalated sapropels

15 levels/38 samples in clays

D. pentaradiatus, $H$. stalis, left coiled N. acostaensis, small-sized $C$. parvulus and G. menardii 4 normal

7.64-7.24 Ma

$37^{\circ} 52^{\prime} \mathrm{N} / 20^{\circ} 44^{\prime} \mathrm{E}$

$60 \mathrm{~m}$ clay and sapropel alternations

Globorotalia menardii 4, small-sized C. parvulus (in the lower part) and G. menardii 5 (in the upper part) and M. convallis, D. brouweri, D. pentaradiatus, and H. brouweri.

normal (first $17 \mathrm{~m}$ ), reversed (next $30 \mathrm{~m})$, normal $(13 \mathrm{~m})$

early Tortonian

$37^{\circ} 41^{\prime} \mathrm{N} / 20^{\circ} 50^{\prime} \mathrm{E}$

$5 \mathrm{~m}$ marly clays with 4 intercalated sapropels

1 site/4 levels/12 cores in the marly clays

Neogloboquadrina acostaensis, small-sized Catapsydrax parvulus without keeled globorotaliids,

Discoaster calcaris and Discoaster hamatus

undetermined

$7.24-6.60 \mathrm{Ma}$

$37^{\circ} 42^{\prime} \mathrm{N} / 20^{\circ} 51^{\prime} \mathrm{E}$

$\sim 300 \mathrm{~m}$ blue clays and sand alternations

1 site/31 levels/97 cores in blue clays

sinistral N. acostaensis, G. conomiozea group and R. rotaria

$250 \mathrm{~m}$ reversed, followed by $50 \mathrm{~m}$ normal 


\section{Appendix A (continued)}

\section{Kalamaki Beach}

Age:

Geographical coordinates:

Lithology:

Cores:

Fossil content:

Magnetostratigraphy:

\section{Alikanes}

Age:

Geographical coordinates:

Lithology:

Cores:

Fossil content:

Magnetostratigraphy:

Gerakas (=ZA 80 118)

Age:

Geographical coordinates:

Lithology:

Cores:

Fossil content:

Magnetostratigraphy:

Zakynthos Town

Age:

Geographical coordinates:

Lithology:

Cores:

Fossil content:

Magnetostratigraphy:

Bochali

Age:

Geographical coordinates:

Lithology:

Cores:

Fossil content:

Magnetostratigraphy:

Porto Roma

Age:

Geographical coordinates:

Lithology:

Cores:

Fossil content:

Magnetostratigraphy:
5.95-5.21 Ma

$37^{\circ} 44^{\prime} \mathrm{N} / 20^{\circ} 53^{\prime} \mathrm{E}$

$125 \mathrm{~m}$ evaporites alternating with clays, followed by $10 \mathrm{~m}$ marls/sapropel

5 levels/15 cores in clays between evaporites and 35 cores in marls/sapropels

Reticulofenestra rotaria in evaporitic part and high relative abundances of Sphaeroidinellopsis and dextral N. acostaensis in the Trubi part (Sphaerodinellopsis Acme Zone).

evaporitic part and base of marls (first $3.5 \mathrm{~m}$ ) is reversed, top marls normal

3.31-2.73 Ma

$37^{\circ} 51^{\prime} \mathrm{N} / 20^{\circ} 47^{\prime} \mathrm{E}$

$10 \mathrm{~m}$ blue clays and sand alternations

2 sites/20 cores in clays

N. acostaensis, G. ruber, G. bononiensis and Discoaster tamalis

overprinted

$1.94-1.61 \mathrm{Ma}$

$37^{\circ} 42^{\prime} \mathrm{N} / 20^{\circ} 58^{\prime} \mathrm{E}$

$\sim 60 \mathrm{~m}$ of laminated clays and sandy alternations

8 levels/28 cores

absence of $H$. balthica and $G$. inflata in the basal, presence of Sphaeroidinella and of $D$.

asymmetricus (reworked)

normal (first metre) followed by reversed

$1.94-1.49 \mathrm{Ma}$

$37^{\circ} 47^{\prime} \mathrm{N} / 20^{\circ} 54^{\prime} \mathrm{E}$

$200 \mathrm{~m}$ clay, sapropel alternations with occasional sand layers

22 levels/64 cores mostly in clays (top of section was not reached)

Discoaster triradiatus, $G$. inflata and no $H$. balthica

normal (first $50 \mathrm{~m}$ ) followed by reversed

$1.37-1.24 \mathrm{Ma}$

$37^{\circ} 48^{\prime} \mathrm{N} / 20^{\circ} 54^{\prime} \mathrm{E}$

scattered outcrops of sandy clay and sand alternations

4 sites/43 cores in clays

large-sized Gephyrocapsa, G. inflata, H. balthica and $100 \%$ right coiled neogloboquadrinids. reversed

$1.03-0.77 \mathrm{Ma}$

$37^{\circ} 42^{\prime} \mathrm{N} / 20^{\circ} 59^{\prime} \mathrm{E}$

outcrops of blue clays in between calcarenites along the coast

11 levels/54 cores

the presence of P. lacunosa, G. inflata and H. balthica together with less than 15-20\% left coiled neogloboquadrinids (in the middle/upper part of the section).

normal (first $10 \mathrm{~m}$ ), reversed (next $5 \mathrm{~m}$ ) followed by a calcarenite and $10 \mathrm{~m}$ of reversed clay, again calcarenite with $10 \mathrm{~m}$ normal clay. 


\section{References}

[1] J. Aubouin, M. Bonneau, J. Davidson, P. Leboulenger, S. Matesco, A. Zambetakis, Esquissse structurale de l'arc égéen externe: des Dinarides aux Taurides, Bull. Soc. Géol. Fr. 18 (1976) 327-336.

[2] A.G. Smith, E.M. Moores, Hellenides, in: A.M. Spencer (Ed.), Mesozoic and Cenozoic Orogenic Belts, Geol. Soc. London Spec. Publ. 4 (1974) 159-185.

[3] Sorel, D., Etude néotectonique des îles ioniennes de Cephalonie et Zante et de l'Elide occidentale (Greece), Thèse du 3me cycle, Univ. Paris-Sud, Faculté Sciences Orsay, 1976.

[4] W. Spakman, Tomographic images of the upper mantle below central Europe and the Mediterranean, Terra Nova 2 (1990) 542-553.

[5] W. Spakman, Subduction beneath Eurasia in connection with the Mesozoic Tethys, Geol. Mijnbouw 65 (1986) 145153.

[6] M.J.R. Wortel, W. Spakman, Structure and dynamics of subducted lithosphere in the Mediterranean region, Proc. Kon. Ned. Akad. Wet. 95 (1992) 325-347.

[7] G. Selvaggi, C. Chiarabba, Seismicity and P-wave velocity image of the Southern Tyrrhenian subduction zone, Geophys. J. Int. 121 (1995) 818-826.

[8] G. Mele, High-frequency wave propagation from mantle earthquakes in the Tyrrhenian Sea: new constraints for the geometry of the south Tyrrhenian subduction zone, Geophys. Res. Lett. 25 (15) (1998) 2877-2880.

[9] M.J. Van der Meulen, J.H. Meulenkamp, M.J.R. Wortel, Lateral shifts of Apenninic foredeep depocentres reflecting detachment of subducted lithosphere, Earth Planet. Sci. Lett. 154 (1998) 203-219.

[10] J.H. Underhill, Late Cenozoic deformation of the Hellenide foreland, western Greece, Geol. Soc. Am. Bull. 101 (1989) 613-634.

[11] C. Laj, M. Jamet, D. Sorel, J.P. Valente, First paleomagnetic results from Mio-Pliocene series of the Hellenic sedimentary arc, Tectonophysics 86 (1982) 45-67.

[12] C. Kissel, C. Laj, The Tertiary geodynamical evolution of the Aegean arc: a paleomagnetic reconstruction, Tectonophysics 146 (1988) 183-201.

[13] C. Kissel, F. Speranza, Paleomagnetism of external southern and central Dinarides and northern Albanides: implications for the Cenozoic activity of the Scutari-Pec transverse zone, J. Geophys. Res. 100 (1995) 14999-15007.

[14] F. Speranza, I. Islami, C. Kissel, A. Hyseni, Paleomagnetic evidence for Cenozoic clockwise rotation of the external Albanides, Earth Planet. Sci. Lett. 129 (1995) 121-134.

[15] A. Morris, M. Anderson, First paleomagnetic results from the Cycladic Massif, Greece, and their implications for Miocene extension directions and tectonic models in the Aegean, Earth. Planet. Sci. Lett. 142 (1996) 397-408.

[16] D. Avigad, G. Baer, A. Heimann, Block rotations and continental extension in the central Aegean Sea: paleomagnetic and structural evidence from Tinos and Mykonos (Cy- clades, Greece), Earth Planet. Sci. Lett. 157 (1998) $23-$ 40.

[17] C. Kissel, C. Laj, A. Malzaud, First paleomagnetic results from Neogene formations on Evvia, Skyros and the Volos region and the deformation of Central Aegea, Geophys. Res. Lett. 13 (1986) 1446-1449.

[18] J.P. Valente, C. Laj, D. Sorel, S. Roy, J.-P. Valet, Paleomagnetic results from Mio-Pliocene marine sedimentary series in Crete, Earth Planet. Sci. Lett. 57 (1982) 159-172.

[19] C. Kissel, A. Poisson, Etude paléomagnétique préliminaire des formations néogène du bassin d'Antalya (Taurides occidentale, Turquie), C.R. Acad. Sci. Paris, 302, II (10) (1986) 711-716.

[20] J. Angelier, N. Lybëris, X. Le Pinchon, E. Barrier, Ph. Hunchon, The tectonic development of the Hellenic arc and the Sea of Crete: a synthesis, Tectonophysics 86 (1982) 159-196.

[21] J.L. Mercier, D. Sorel, K. Simeakis, Changes in the state of stress in the overriding plate of a subduction zone; the Aegean arc from the Pliocene to the present, Ann. Tectonicae 1 (1987) 20-39.

[22] T. Taymaz, J. Jackson, D. McKenzie, Active tectonics of the north and central Aegean Sea, Geophys. J. Int. 106 (1991) 433-490.

[23] C.E. Duermeijer, W. Krijgsman, C.G. Langereis, J.H. Ten Veen, Post early Messinian counter-clockwise rotations on Crete: implications for the Late Miocene to Recent kinematics of the southern Hellenic Arc, Tectonophysics 298 (1998) 177-189.

[24] D.P. Kondopoulou, S.B. Pavlides, Paleomagnetic and neotectonic evidence for different deformation patterns in the south Aegean volcanic arc: the case of the Melos island, Int. Earth. Sci. Congr. Aegean Regions, Proc. 1 (1990) 210-233.

[25] F.J. Hilgen, W. Krijgsman, C.G. Langereis, L.J. Lourens, A. Santarelli, W.J. Zachariasse, Extending the astronomical (polarity) time scale into the Miocene, Earth Planet. Sci. Lett. 136 (1995) 495-510.

[26] W. Krijgsman, F.J. Hilgen, C.G. Langereis, A. Santarelli, W.J. Zachariasse, Late Miocene magnetostratigraphy, biostratigraphy and cyclostratigraphy in the Mediterranean, Earth Planet. Sci. Lett. 136 (1995) 475-494.

[27] L.J. Lourens, A. Antonarakou, F.J. Hilgen, A.A.M. Van Hoof, C. Vergnaud-Grazzini, W.J. Zachariasse, Evaluation of the Plio-Pleistocene astronomical timescale, Paleoceanography 11 (4) (1996) 391-413.

[28] C.E. Duermeijer, N. van Vugt, C.G. Langereis, J.E. Meulenkamp, W.J. Zachariasse, A major late Tortonian rotation phase of the Crotone Basin; implications using AMS as tectonic tilt correction and first indication of timing in opening of the Tyrrhenian Basin, Tectonophysics 287 (1998) 233249.

[29] C.E. Duermeijer, C.G. Langereis, Astronomical dating of a tectonic rotation on Sicily and consequences for the timing and extent of a middle Pliocene deformation phase, Tectonophysics 298 (1998) 243-258.

[30] L. Sagnotti, Paleomagnetic evidence for a Pleistocene coun- 
ter-clockwise rotation of the Sant'Arcangelo Basin, southern Italy, Geophys. Res. Lett. 19 (2) (1992) 135-138.

[31] Scheepers, P.J.J., Tectonic Rotations in the Tyrrhenian Arc System during the Quaternary and Late Tertiary, $\mathrm{PhD}$ thesis, Utrecht University, Geol. Ultraiectina 112, 1994, 352 pp.

[32] G. Bizon, C. Muller, La limite Pliocène-Pleistocène dans l'ile de Zante. La coupe de la Citadelle, C.R. Soc. Géol. Fr. 4 (1977) 212-216.

[33] M.V. Triantaphyllou, Biostratigraphical and Ecostratigraphical Observations Based on Calcareous Nannofossils, of the Eastern Mediterranean Plio-Pleistocene Deposits, PhD thesis, Athens University, Gaia 1, 1996, 229 pp.

[34] J.H. Underhill, Triassic evaporites and Plio-Quaternary diapirism, western Greece, J. Geol. Soc. London 145 (1988) 269-282.

[35] M.D. Dermitzakis, D. Papanikolaou, Z. Karotsieris, The marine Quaternary formations of SE Zakynthos island and their paleogeographic implications, Proc. 6th Geol. Aegean Region, Athens, I, 1979, pp. 407-415.

[36] M.V. Triantaphyllou, H. Drinia, M.D. Dermitzakis, The Plio-Pleistocene boundary in the Gerakas section, Zakynthos (Ionian Islands), biostratigraphical and paleoecological observations, Neues Jahrb. Geol. Paläontol. Monatsh. 1 (1997) 12-30.

[37] A.A.M. Van Hoof, B.J.H. Van Os, J.G. Rademakers, C.G. Langereis, G.J. De Lange, A paleomagentic and geochemical record of the upper Cochiti reversal and two subsequent precessional cycles from southern Sicily (Italy), Earth Planet. Sci. Lett. 117 (1993) 235-250.

[38] W. Krijgsman, F.J. Hilgen, I. Raffi, F.J. Sierro, D.S. Wilson, Messinian astrochronology for the salinity crisis. Nature (in press).

[39] W.A. Berggren, F.J. Hilgen, C.G. Langereis, D.V. Kent, J.D. Obradovich, I. Raffi, M.E. Raymo, N.J. Shackleton, Late Neogene chronology: New perspectives in high-resolution stratigraphy, Geol. Soc. Am. Bull. 107 (1995) 1272-1287.

[40] W.A. Berggren, D. Kent, C.C. Swisher, III, M.-P. Aubry, A revised Cenozoic geochronology and chronostratigraphy, in: Geochronology Time-scales and Global Stratigraphic Correlation, Soc. Econ. Paleontol. Mineral. Spec. Publ. 54 (1995) 129-212.

[41] L.J. Lourens, F.J. Hilgen, I. Raffi, Base of large Gephyrocapsa and astronomical calibration of early Pleistocene sapropels in site 967 and Hole 969D: solving the chronol- ogy of the Vrica section (Calabria, Italy), Proc. ODP, Sci. Results 160 (1998) 191-197.

[42] C.G. Langereis, M.J. Dekkers, G.J. de Lange, M. Paterne, P.J.M. van Santvoort, Magnetostratigraphy and astronomical calibration of the last 1.1 Myr from an eastern Mediterranean piston core and dating short events in the Bruhnes, Geophys. J. Int. 129 (1997) 75-94.

[43] C.G. Langereis, A.A.M. van Hoof, P. Rochette, Longitudinal confinement of geomagnetic reversal paths as a possible sedimentary artefact, Nature 358 (1992) 226-230.

[44] P.J.J. Scheepers, C.G. Langereis, Analysis of NRM-directions from the Rossello composite: implications for tectonic rotations of the Caltanisetta basin (Sicily), Earth Planet. Sci. Lett. 119 (1993) 243-258.

[45] W. Lowrie, Identification of ferromagnetic minerals in a rock by coercivity and unblocking temperature properties, Geophys. Res. Lett. 17 (2) (1990) 159-162.

[46] J. Mercier, E. Carey, H. Phillip, D. Sorel, La néotectonique Plio-Quaternaire de l'arc égéen externe et de la mer Egée et ses relations avec la seismicité, Vme Coll. Géol. Régions Egéennes, Orsay, février 1975, Bull. Soc. Géol. Fr. (7), 19 (1976) 355-372.

[47] W. Spakman, M.J.R. Wortel, N.J. Vlaar, The Hellenic subduction zone: a tomographic image and its geodynamic implications, Geophys. Res. Lett. 15 (1) (1988) 60-63.

[48] S.J.H. Buiter, M.J.R. Wortel, R. Govers, The role of subduction in the evolution of the Apennines foreland basin, Tectonophysics 296 (1998) 249-268.

[49] D. Sorel, J.-L. Mercier, B. Keraudren, M. Cushing, The role of slab-pull force in the Plio-Pleistocene geodynamic evolution of the Aegean arc: subsidence and uplift of the external arc and changes in the tectonic regime, C. R. Acad. Sci. Paris 307 (1988) 1981-1986.

[50] R. Westaway, Quaternary elevation change of the Gulf of Corinth in central Greece, Philos. Trans. R. Soc. London. A 354 (1996) 1125-1164.

[51] J.-L. Mercier, La néotectonique. Ses méthodes et ses buts. Un exemple: l'arc égéen (Méditerranée orientale), Rev. Géogr. Phys. Géol. Dyn. (2), XVIII, 4 (1976) 323-346.

[52] P.Th. Meijer, M.J.R. Wortel, Temporal variation in the stress field of the Aegean region, Geophys. Res. Lett. 23 (1996) 439-442.

[53] R. Westaway, Quaternary uplift of southern Italy, J. Geophys. Res. 98 (B12) (1993) 21741-21772. 